\title{
Prophylactic effect of herbal-marine compound (HESA-A) on influenza A virus infectivity
}

Parvaneh Mehrbod ${ }^{1,2}$, Aini Ideris ${ }^{1,2^{*}}$, Abdul Rahman Omar ${ }^{1,2}$ and Mohd Hair-Bejo ${ }^{1,2}$

\begin{abstract}
Background: Influenza virus is still a severe respiratory disease affecting human and other species. As conventional drugs are not recommended for long time because of side effects and drug resistance occurrence, traditional medication has been focused as alternative remedy. HESA-A is a natural compound from herbal-marine origin. Previous studies have reported the therapeutic properties of HESA-A on psoriasis vulgaris and different types of cancers and we also showed its anti-inflammatory effects against influenza A infection.

Methods: This study was designed to investigate the potential properties of HESA-A as prophylaxis or treatment. To investigate the prophylaxis or treatment activities of HESA-A, Madin-Darby Canine Kidney (MDCK) cells were exposed to HESA-A and influenza A virus in different manners of exposure and different time intervals. The results were evaluated by MTT and HA assays.
\end{abstract}

Results: It was found that HESA-A is much more effective against influenza cytopathic effects when it is applied for prophylaxis and also in concurrent treatment $(p \leq 0.05)$ but not in post-infection treatment $(p \geq 0.05)$.

Conclusion: In conclusion, HESA-A is significantly effective against influenza replication in prophylaxis application affecting the virus penetration/adsorption to the cell without any toxic effect on the cell viability.

Keywords: HESA-A, H1N1, Influenza virus, HA, MTT

\section{Background}

Influenza A virus as a member of the Orthomyxoviridea family results in significant morbidity and high rates of mortality worldwide annually. Vaccines which are the best option to prevent this infection cannot be trusted because of the lag time between virus identification and vaccine distribution which may cause devastating outcomes. Conventional approved antiviral drugs such as amantadine and oseltamivir [1] which are helpful to control the spread of influenza disease from the host cell [2] may not be suggested any longer due to various genetic drift and shift mutations which cause alterations in the antibodytargeted surface glycoproteins [3] and negative side effects and rapid emergence of resistant variants [4,5]. Therefore, they are not recommended for uncontrolled usage [6]. Thus, additional antiviral alternatives preferably with natural origin easily available for the prevention/treatment

\footnotetext{
*Correspondence: aiini@upm.my

${ }^{1}$ Faculty of Veterinary Medicine, Universiti Putra Malaysia, 43400 Serdang, Selangor, Malaysia

${ }^{2}$ Institute of Bioscience, Universiti Putra Malaysia, 43400 Serdang, Selangor, Malaysia
}

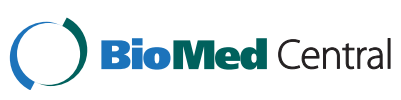

of influenza A infections with low/no side effect is highly demanded.

HESA-A is an active natural biological compound from herbal-marine origin, with a general composition of organic, inorganic and aqueous fractions [7]. Previous studies have reported the therapeutic properties of HESAA against psoriasis vulgaris, breast cancer and choroidal metastasis [8-10]. In our previous study on HESA-A, we showed the antiviral activity of this compound on influenza replication by affecting hypercytokinemia decreasing TNF- $\alpha$ and IL- 6 expression levels [11]. In the current study we evaluated the preventive or treatment activity of HESA-A on influenza replication in different exposures and time intervals.

\section{Methods}

\section{Reagents and chemicals}

Cell culture media and penicillin-streptomycin solution 100x were purchased from Mediatech Cellgro Company (Northbrook, Illinois, USA). Fetal bovine serum (FBS) was purchased from PAA Laboratories (Pasching, Austria). 
HESA-A was kindly provided by Dr. Amrollah Ahmadi, Tehran University of Medical Sciences, Tehran, IRAN. (3-(4, 5-dimethylthiazol-2-yl)-2, 5-diphenyltetrazolium bromide, MTT), and Tosylamide Phenylethyl Chloromethyl Keton-treated Trypsin (Trypsin TPCK) were purchased from Sigma (Saint Louis, Missouri, USA).

\section{HESA-A preparation}

Briefly, it was dissolved in normal saline, shaken for 30 minutes and filtered to become homogenate. Prior to its use, the stock solution $(0.8 \mathrm{mg} / \mathrm{ml}, \mathrm{pH} 7.4)$ was sterilized through $0.22 \mu \mathrm{m}$ syringe filter [12]. It was diluted with DMEM to $0.025 \mathrm{mg} / \mathrm{ml}$ concentration as $\mathrm{EC}_{50}$ [11].

\section{Cell culture and influenza A virus propagation}

Influenza A virus strain New Jersey/8/76; H1N1 [A/NJ (H1N1)] was purchased from American Type Culture Collection (ATCC) (reference number: VR-897 ${ }^{\mathrm{TM}}$ ) which was propagated on Madin Darby canine kidney (MDCK) cell line $\left(\mathrm{CCL}-34^{\mathrm{TM}}\right)$. Cells were grown in Dulbecco's modified Eagle's medium (DMEM) containing 10\% heatinactivated FBS, 100 units/ml penicillin $\mathrm{G}$ and $100 \mu \mathrm{g} / \mathrm{ml}$ streptomycin. Cultured cells were incubated at $37^{\circ} \mathrm{C}$ in the presence of $5 \% \mathrm{CO}_{2}$. To propagate influenza A virus, cells were washed with PBS to remove residual FBS and were infected with influenza A virus at MOI of 0.5 in serumfree DMEM for $60 \mathrm{~min}$ at $37^{\circ} \mathrm{C}$ (adsorption phase). Progeny virus was harvested three days post-infection. Standard hemagglutination test (HA) was carried out to measure the viral titer [11].

\section{HESA-A anti-viral effect on the virus}

MDCK cells seeded in 96-well plate were exposed to different combination treatments of HESA-A and influenza $A$ virus $\left(100 \mathrm{TCID}_{50} / 0.1 \mathrm{ml}\right)$ in different time intervals. HESA-A in a non-cytotoxic concentration was used for antiviral assays. It was added to MDCK cells before, concomitantly with or after H1N1 infection in 1, 8 and $24 \mathrm{hr}$ time points. In brief, monolayers of MDCK cells were treated with HESA-A for 1,8 or $24 \mathrm{hr}$, which was washed away before infection with H1N1 for $1 \mathrm{hr}$ (pretreatment assay), HESA-A and $\mathrm{H} 1 \mathrm{~N} 1$ were added to the cell layer together during the 1,8 or $24 \mathrm{hr}$ infection period (co-treatment assay), or HESA-A was added for 1,8 or $24 \mathrm{hr}$ right after the infection period for $1 \mathrm{hr}$ (post-treatment assay). After all the treatments in allocated time, cells were washed with PBS and covered with medium containing Trypsin_TPCK $(1 \mu \mathrm{g} / \mathrm{ml})$ for $48 \mathrm{hr}$.

\section{MTT cell viability assay}

MDCK cells were incubated in 96-well microplate (Nunc, Denmark) for $24 \mathrm{hr}$ at $37^{\circ} \mathrm{C}$ to reach the confluency. Following treatments based on the experimental design, colorimetric MTT assay was performed according to
Mehrbod et al. [13]. Briefly, the media was removed and $100 \mu \mathrm{l}$ of $1 \times \operatorname{MTT}$ (3-(4, 5-dimethylthiazol-2-yl)-2, 5 -diphenyltetrazolium bromide, Sigma) was added to each well. Following incubation at $37^{\circ} \mathrm{C}$ for $2-3 \mathrm{hr}, 100 \mu \mathrm{l}$ of DMSO was added and mixed thoroughly to release the colour. The absorbance of colour in the solution was analyzed at $540 \mathrm{~nm}$ with microplate reader machine (BioTek EL 800, US) to calculate viability of the cells by one way ANOVA, SPSS.

\section{Hemagglutination assay}

To evaluate the presence of the virus in cell culture, either virus-inoculated or combined-treated samples, supernatants of the culture media were exposed to chicken red blood cells (cRBCs) (0.5\%). The assay was carried out as described previously by Mehrbod et al. [13]. The significant differences were analyzed using one way ANOVA, SPSS.

\section{Statistical analysis}

The data expressed as mean $\pm \mathrm{SD}$ was gathered and analyzed using analysis of variance (ANOVA) Tukey post-hoc test (SPSS 18.0). Sample values between different groups and treatments with $\mathrm{p} \leq 0.05$ were considered statistically significant.

\section{Results and discussion}

In this experiment, to evaluate the protective effect of non-toxic concentration of HESA-A $(0.025 \mathrm{mg} / \mathrm{ml})$ in combination treatments with $\mathrm{H} 1 \mathrm{~N} 1$ in different time points, MTT viability test was conducted following incubation periods. As expected, HESA-A treatment in $0.025 \mathrm{mg} / \mathrm{ml}$ concentration did not show any significant difference with the control ( $p \geq 0.05)$, while H1N1 treatments caused significant decrements in cell viability as compared to the control $(\mathrm{p} \leq 0.05)$. However, there was significant increment in optical densities (ODs) in different combination exposures as compared to virusinoculated sample $(\mathrm{p} \leq 0.05)$ except for post-treatments $(\mathrm{p} \geq 0.05)$. The results are shown in Figure 1 .

Based on hemagglutination titration, the inhibitory effect of HESA-A on viral activity was shown by highly significant reduction in Log HA titre in all combination treatments $(\mathrm{p}<0.01)$. The results are shown in Figure 2.

Influenza A virus is the major cause of respiratory tract infections in a variety of species [14]. Unsuccessful treatment of this disease is related to its constant evolving genome which makes it extremely difficult to develop effective vaccines as well as antiviral drugs [15]. Thus, developing novel anti-influenza compounds, preferably of natural origin and low side effects are required [16,17]. HESA-A which is a patented natural product in IRAN, has been used against different types of diseases like wide range of cancers, psoriasis vulgaris and autoimmune 


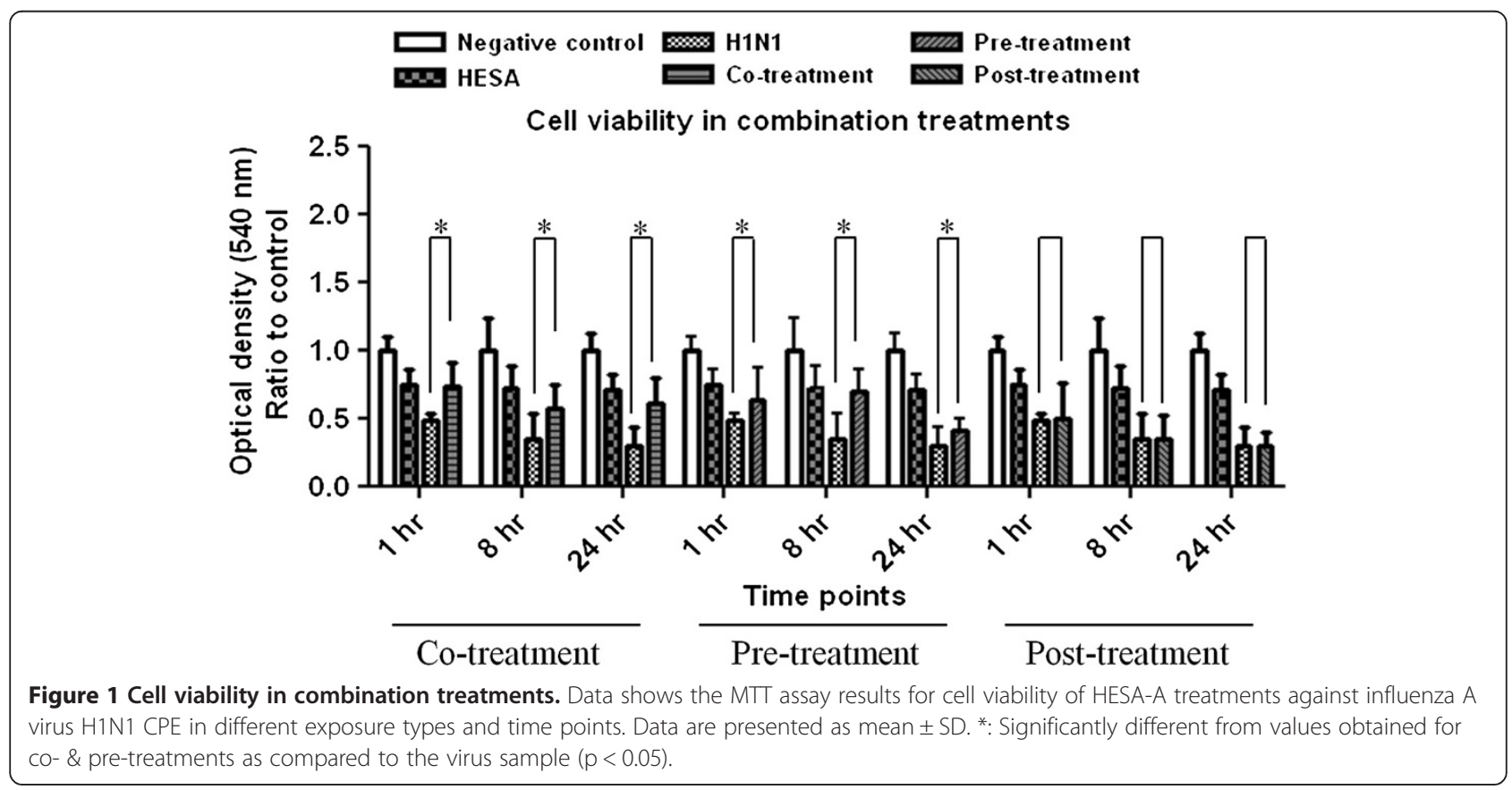

diseases by decreasing the inflammatory responses and improving the patients' quality of life $[9,10,18]$. In our previous research on HESA-A focusing on its antiviral activity against influenza $\mathrm{A}$ virus $\mathrm{H} 1 \mathrm{~N} 1$, the $\mathrm{EC}_{50}$ (effective concentration) of this compound was obtained at $0.025 \mathrm{mg} / \mathrm{ml}$ with no cytotoxic effect on MDCK cells and its anti-inflammatory effects against two important inflammatory cytokines; TNF- $\alpha$ and IL- 6 was verified in genome and protein level in $1 \mathrm{hr}$ exposure time. The results showed the inhibitory effects of HESA-A on H1N1 infection. In the present study we confirmed the inhibitory effects of HESA-A on influenza infection by different types of combination treatments in different time points. Data from viability test showed that co- \& pre-treatments but not post-treatment, even in short incubation times protected the cell viability against H1N1 CPE significantly $(\mathrm{p} \leq 0.05)$. However, data from HA assay showed highly significant decrements in HA titers in all combination

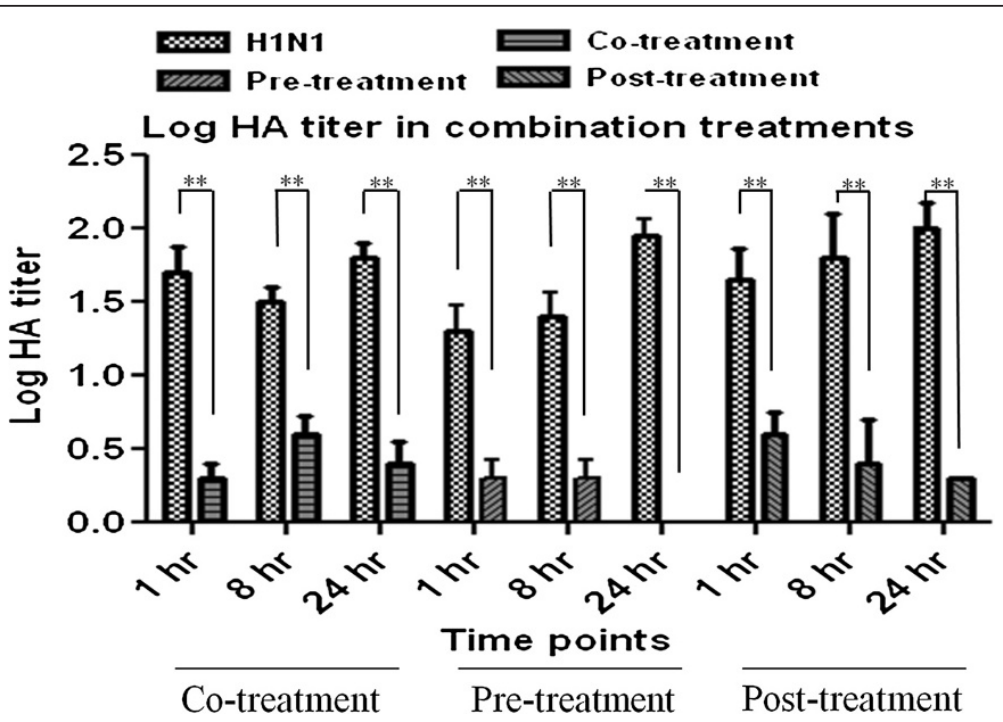

Figure 2 Log HA titer reduction in HESA-A treatments against H1N1. The HA data showed highly significant decrements in all combination treatments as compared to the H1N1 sample. Data are presented as mean \pm SD. ${ }^{*}$. Highly significantly different from values obtained for combination treatments as compared to the virus sample $(p<0.01)$. 
treatments even post-treatment $(\mathrm{p} \leq 0.01)$. From these results it is postulated that post-treatment cannot protect the cell viability from viral $\mathrm{CPE}$, therefore, the decrease in HA titer in this type of exposure means no viable cell presence to support the viral replication. In conclusion, supporting achievements from previous study which showed the effects of HESA much stronger than amantadine and also supporting data from current study, suggest that HESA-A as a natural product has the potential of supplementary medication or alternative to antiviral agents to inhibit influenza infection especially in the first steps of its infection cycle by prophylactic effects affecting the virus penetration/adsorption. More detailed investigation on viral and cellular pathways could be of interest to evaluate the localization of function of HESA-A on virus-host interaction system.

\section{Conclusion}

In conclusion, supporting achievements from previous study which showed the effects of HESA much stronger than amantadine and also supporting data from current study, suggest that HESA-A as a natural product has the potential of supplementary medication or alternative to antiviral agents to inhibit influenza infection especially in the first steps of its infection cycle by prophylactic effects affecting the virus penetration/adsorption. More detailed investigation on viral and cellular pathways could be of interest to evaluate the localization of function of HESA-A on virus-host interaction system.

\footnotetext{
Abbreviations

ANOVA: Analysis of variance; ATCC: American Type Culture Collection; CPE: Cytopathic effect; DMEM: Dulbecco's modified Eagle's medium; $\mathrm{EC}_{50}$ : Effective concentration; FBS: Fetal bovine serum; HA: Hemagglutination assay; MDCK: Madin-Darby Canine Kidney; TPCK: Tosylamide Phenylethyl Chloromethyl Keton-treated Trypsin.
}

\section{Competing interests}

The authors declare that they have no competing interests.

\section{Authors' contributions}

PM and Al co-defined the research theme. PM designed the methods and experiments. She carried out the laboratory experiments, worked on the associated data collection and their interpretation and drafted the manuscript. $\mathrm{PM}, \mathrm{Al}, \mathrm{ARO}$ and $\mathrm{MH}-\mathrm{B}$ revised the paper critically for important intellectual content. All authors have seen and approved the manuscript.

\footnotetext{
Acknowledgments

Our sincere gratitude to Dr. Amrollah Ahmadi, from Tehran University of Medical Sciences, Tehran, IRAN, who kindly provided HESA-A. This study was funded by Grant Number 01-02-04-009 BTK/ER/38 from the Ministry of Science, Technology and Innovation, Government of Malaysia.
}

Received: 19 September 2013 Accepted: 31 March 2014 Published: 7 April 2014

\section{References}

1. Sarah $C D$, Hong M: Amantadine-induced conformational and dynamical changes of the influenza M2 transmembrane proton channel. Proc Natl Acad Sci USA 2008, 105:1483-1488.
2. Calero M, Chen CZ, Zhu W, Winand N, Havas KA, Gilbert PM, Burd CG, Collins RN: Dual prenylation is required for Rab protein localization and function. Mol Biol Cell 2003, 14:1852-1867.

3. Wagman PC, Leong MA, Simmen KA: Development of a novel influenza A antiviral assay. J Virol Method 2002, 105:105-114.

4. Dai J-P, Li W-Z, Zhao X-F, Wang G-F, Yang J-C, Zhang L, Chen X-X, Xu Y-X, Li K-S: A drug screening method based on the autophagy pathway and studies of the mechanism of evodiamine against influenza $A$ virus. PLoS One 2012, 7:e42706.

5. Pathumwadee I, Chittima L, Thanyada R, Arthorn L, Maturos M, Panita D, Ornjira A, Krit C, Nopphorn K, Pornthep S, Somsak P, Supot H: How amantadine and rimantadine inhibit proton transport in the $M 2$ protein channel. J Mol Graph Model 2008, 27:342-348.

6. Fiore AE, Shay DK, Broder K, Iskander JK, Uyeki T, Mootrey G, Bresee JS, Cox NJ: Prevention and control of influenza: recommendations of the Advisory Committee on Immunization Practices (ACIP). Recomm Report 2008, 57:1-60

7. Moallem S, Ahmadi A, Moshafi M, Taghavi M: Evaluation of fetal toxicity of HESA-A, a natural anticancer agent, in mice. J Kerman Med Sci 2007, 14:124-133.

8. Ahmadi A, Balali-Mood K, Ghafghazi T, Rajabi P, Taher M: Toxicity evaluation of an antitumor marine compound (HESA-A) in mice and rats. J Birjand Univ Med Sci 2005, 12:3-18.

9. Ahmadi A, Barikbin B, Naseri M, Mohagheghi M: The effect of HESA-A on psoriasis vulgaris. J Drug Dermatol 2008, 7:559-561.

10. Ahmadi A, Mohagheghi MA, Fazeli MS, Nahavandian B, Bashardoost N, Musavi JA, Gharipoor M: HESA-A, a new treatment for breast cancer and choroidal metastasis. Med Sci Monit 2005, 11:CR300-CR303.

11. Mehrbod P, Ideris A, Omar AR, Hair-Bejo M, Tan SW, Kheiri MT, Tabatabaian M: Attenuation of influenza virus infectivity with herbal-marine compound (HESA-A): an in vitro study in MDCK cells. Virol J 2012, 9:44.

12. Sadeghi $A H, A$ hmadi $A$ : Cytotoxicity and antitumor properties of a marine compound, HESA-A, on cancer cells. DARU 2003, 11:82-87.

13. Mehrbod P, Motamed N, Tabatabaian M, Soleimani Estyar R, Amini E, Shahidi M, Kheiri MT: In vitro antiviral effect of "Nanosilver" on influenza virus. DARU 2009, 17:88-93.

14. Rossman JS, Lamb RA: Autophagy, apoptosis, and the influenza virus M2 protein. Cell Host Microbe 2009, 6:367-380.

15. Fedson DS: Pandemic influenza: a potential role for statins in treatment and prophylaxis. Clin Inf Dis 2006, 43:199-205.

16. Kitazato K, Wang Y, Kobayashi N: Viral infectious disease and natural products with antiviral activity. Drug Discov Ther 2007, 1:14-22.

17. Vahabpour RR, Shamsi SM, Monavari SH, Sajjadi SEN: Evaluation of potential antiviral activity of hydroalcoholic extract of lemon balm L. against herpes simplex virus type-I. Iran J Virol 2007, 1:28-32.

18. Ahmadi A: A study of thirty patients with metastatic liver cancer and hepatocellular carcinoma treated with HESA-A. In Fifth AACR International Conference on Frontiers in Cancer Prevention Research. USA: AACR Meeting Abstracts Online; 2006.

doi:10.1186/1472-6882-14-131

Cite this article as: Mehrbod et al:: Prophylactic effect of herbal-marine compound (HESA-A) on influenza A virus infectivity. BMC Complementary and Alternative Medicine 2014 14:131.

\section{Submit your next manuscript to BioMed Central and take full advantage of:}

- Convenient online submission

- Thorough peer review

- No space constraints or color figure charges

- Immediate publication on acceptance

- Inclusion in PubMed, CAS, Scopus and Google Scholar

- Research which is freely available for redistribution 